\title{
Thermodynamic Analyses of Compressed Air Energy Storage System with Partial Oxidation Gas Turbine Technology
}

\author{
Marlena Wróbel and Jacek Kalina
}

\begin{abstract}
This article presents thermodynamic calculations and initial optimization of the conceptual technological system, connecting an energy storage system in compressed air (CAES) with partial oxidation gas turbine (POGT). Concept of operation of such system and way of calculations is presented. The CAES with POGT system is analyzed with the help of an energy balance. Optimization based on maximization of energy efficiency was performed. The obtained results were compared with other cases.
\end{abstract}

Index Terms-CAES, POGT, energy storage.

\section{INTRODUCTION}

In conception of future sustainable energy systems demand the introduction of integrated with energy system, storage technologies. Looking for more and more efficient and flexible energy storage systems are currently in scope of many scientific studies as well as intensive R\&D activities worldwide. Energy storage technologies are being developed due to the high demand for energy storage in power systems. For example emergency power supply or energy storage from renewable sources [1]. To accumulate large volume of energy, pumped-storage systems have the biggest share (99\%) in installed power compared to other energy storage technologies used worldwide [2]. The advantages of this technology are the possibility of short start-up time, storage for any length of time, cheap and commonly available energy carrier, low cost of energy generation, maturity of technology and long lifetime. The most important disadvantages of this technology are: the dependability on hydro geological conditions, high investment expenditure and changes in the eco system [3]. An important alternative to pumped hydro storage plants are Compressed Air Energy Storage (CAES) systems [4]. The main advantage of this installation include use of a free energy carrier i.e. air. In a classical CAES installation electric energy available outside the peak is used for compressing air which is stored in an underground cavers or ground vessels. If there is a need to generate electricity, compressed air is mixed with natural gas, burnt and decompressed in expander, thus powering the generator. This

Manuscript received Sep. 25, 2018; revised March 28, 2019

The authors are with Institute of Thermal Technology, Silesian University of Technology Konarskiego 22; 44-100 Gliwice, Poland (e-mail:marlena.wrobel@polsl.pl). paper proposes the concept of incorporation of the partial oxidation gas turbine (POGT) technology into the CAES system to increase the efficiency of energy storage.

\section{SYSTEM CONCEPTION}

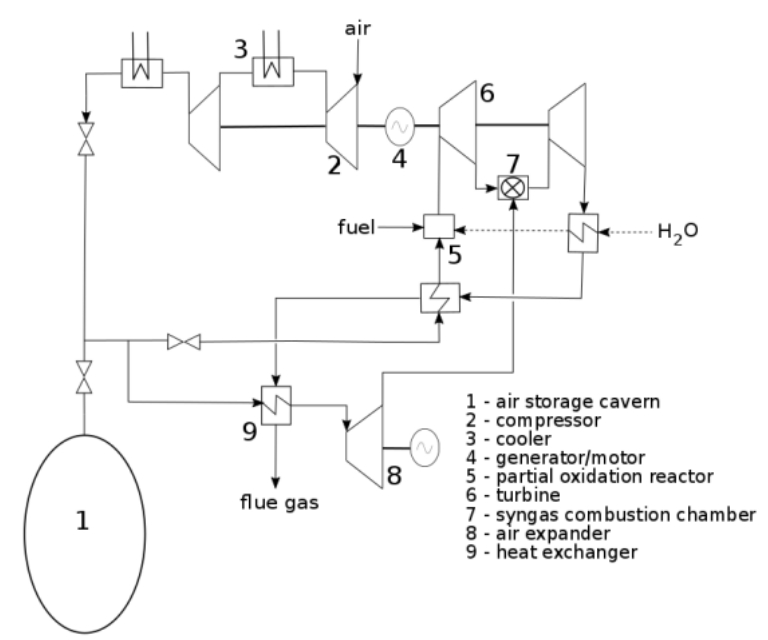

Fig. 1. Diagram of CAES system with POGT.

The conceptual layout includes the connection of the CAES system with the POGT installation. A partial oxidation gas turbine is characterized by the presence of a partial oxidation reactor at the location of the combustion chamber in gas turbine. Partial oxidation is a process where quantity of oxidizer is less than that stoichiometric air ratio requested for the complete combustion of a hydrocarbon fuel. As a result of chemical reactions occurring under substoichiometric conditions, a gas containing combustible parts such as $\mathrm{CO}$ or $\mathrm{H}_{2}$. The resulting gas can be burned or used in other ways (e.g. for the production of hydrogen). The division of the oxidation process of fuel leads to a reduction of demand for the compressed air in the system and thus the driving energy for the compressors. What is more, POGT systems feature low $\mathrm{NO}_{\mathrm{x}}$ emissions [5]. Comparing to standard GT system POGT system obtains higher, about 10 percentage points, efficiency of electricity generation [6]. The article presents the proposal of usage of the POGT system in the existing Huntorf CAES installation in Germany. In this installation compressed air is stored in two salt caverns with a capacity of approx. 300000 $\mathrm{m}^{3}$ [7]. The designed power of the system is $290 \mathrm{MW}$, using a two-stage gas turbine and two combustion chambers. The total power of two stage compressors is about $60 \mathrm{MW}$. During compression process, intermediate coolers were also used [8]. Diagram of the conceptual layout of the installation 
is presented in Fig. 1. The figure shows the use of partial oxidation reactor with a water vapour injection technology [9]. Heating air system with recuperators is also applied. Additional element used in this system is expander of the air supplied to the low pressure syngas combustion chamber.

\section{A. Assumptions}

Calculations of the original design parameters of the system were preserved such as: the volume of air storage, work pressures of air, streams of compressed and expended air. Other adopted assumptions are presented in Table I.

TABLE I: ASSUMPTIONS TO SimULATION MODEL INPUT [7], [8], [10]

\begin{tabular}{lll}
\hline \hline Operating condition & Value & Unit \\
\hline Compressor total power & 60 & $\mathrm{MW}$ \\
Atmospheric air pressure & 0,1013 & $\mathrm{MPa}$ \\
Atmospheric air temperature & 10 & ${ }^{\circ} \mathrm{C}$ \\
Compressed air flow & 108 & $\mathrm{~kg} / \mathrm{s}$ \\
Cavern operating pressure & $4,6-6,6$ & $\mathrm{MPa}$ \\
Compressor outlet & 50 & ${ }^{\circ} \mathrm{C}$ \\
temperature & 417 & $\mathrm{~kg} / \mathrm{s}$ \\
Discharge air consumption & 4.2 & $\mathrm{MPa}$ \\
HP turbine inlet pressure & $2 \times 150000$ & $\mathrm{~m}^{3}$ \\
Air storage volume & 50000 & $\mathrm{~m}^{2}$ \\
Caverns surface & methane & - \\
Fuel & 8 & $\mathrm{~W} / \mathrm{m}^{2} \mathrm{~K}$ \\
Convective heat transfer & & \\
coefficient & & \\
\hline \hline
\end{tabular}

Other parameters of the system work have been optimized in the further part of this work

\section{B. Calculation model}

The calculation would be divided into two parts. In the first dynamic air compression system, modelled in Matlab ${ }^{\circledR}$ software and the other, power generation part, modeled in the EBSILON $^{\circledR}$ Professional program.

The cavern charging is a dynamic process where ordinary differential equations were solved numerically. The Crank-Nicolson predictor-corrector method was used.

The compression cycle and air charging at CAES power plant was modelled using own calculation codes developed in the Matlab® software with CoolProp thermophysical property library [11]. The calculations were based on mass (1), and energy (2) balances of the air cavern:

$$
\begin{gathered}
\frac{d \rho}{d t}=\frac{\dot{m}_{i n}}{V} \\
\frac{d U}{d t}=\dot{m}_{i n} \cdot h_{i n}-\dot{Q}_{a m}
\end{gathered}
$$

$\rho$ : density

$t$ : time

$m_{\text {in }}$ : input air mass flow

$V$ : cavern volume

$U$ : internal energy

$h_{\text {in }}$ : input air specific enthalpy

$Q_{a m}$ : ambient heat losses

The air volume was assumed to be humid gas treated as perfect mixture instead of real gasses including moisture. Heat flow phenomena in salt caverns has been simplified. It was assumed that the temperature of the cavern's wall is equal to the temperature of the salt massif, and the temperature inside the cavern is homogeneous. Calculation of heat losses through tank walls has been approximated by the equation. (3).

$$
\dot{Q}_{a m}=\alpha \cdot A_{c}\left(T-T_{c w}\right)
$$

$\alpha$ : heat transfer coefficient

$A_{c}$ : caverns surface

$T$ : air temperature in cavern

$T_{c w}$ : cavern wall temperature

Calculations of the power generation system were made using the EBSILON ${ }^{\circledR}$ Professional software. Since the operating pressure range in the caverns is between $6,6-4,6$ $\mathrm{MPa}$, and the air supplied to the POR is throttled to the pressure of 4,2 MPa, it has been assumed that the expansion process can be simplified to a steady state model. An important task was to properly calculate the reactions in the POR, for this purpose the "Gibbs reactor" component model of the EBSILON ${ }^{\circledR}$ Professional was used. This component performs chemical equilibrium calculations through minimization of the Gibbs free enthalpy:

$$
\sum_{i=1}^{i=n c} \sum_{j=1}^{j=n p} n_{j i}\left[g_{j i}^{0}(T, p)+R T \ln \left(z_{j i}\right)\right] \rightarrow \min
$$

$i$ : component index

$j:$ phase index

$n c$ : number of components

$n p$ : number of phases

$g_{j i}^{0}(T, p)$ : specific Gibbs enthalpy of pure component $i$ in phase $j$

$p$ : pressure

$R$ : universal gas constant $(8,314 \mathrm{~J} / \mathrm{molK})$

$z_{j i}$ : molar fraction of component $i$ in phase $j$

Specific Gibbs free enthalpy of component $i$ is:

$$
g_{i}^{0}(T, p)=h_{i}^{0}(T)-T s_{i}^{0}(T, p)
$$

$h_{i}^{0}$ : specific enthalpy of pure component $i$

$s_{i}^{0}$ : specific entropy of pure component $i$

\section{RESULTS}

\section{A. Results}

The first stage of the calculations was to simulate the section of compression and accumulation of air. Dynamic calculations were made in the Matlab software, and the results are presented in Table II.

TABLE II: RESULTS OF CALCULATIONS

\begin{tabular}{lll}
\hline \hline Data & Value & Unit \\
\hline Input of electricity energy & 3576,43 & $\mathrm{GJ}$ \\
Charging time & 16,833 & $\mathrm{~h}$ \\
Amount of stored air & 6544800 & $\mathrm{~kg}$ \\
\hline \hline
\end{tabular}

Obtained results, especially the electrical power consumption, were used in calculations and optimization of power generation section.

\section{B. Optimization of Discharge System}

Optimization of analysed system was focused on round trip efficiency increasing, defined by the formula (6) 


$$
\eta=\frac{E_{\text {el.out }}}{E_{\text {el. } . n}+Q_{f}}
$$

$E_{\text {el.out }}$ : net output electrical energy

$E_{\text {el.in }}$ : input electrical energy

$Q_{f}$ : fuel energy input

An important issue is the possibility of solid carbon fraction (soot) occurrence in the partial oxidation plant. It is caused due to the substoichiometric conditions present in the POR. The formation of soot might have a detrimental effect to operation of the installation, causing contamination of equipment. In order to reduce the amount of solid carbon fraction, steam injection into the reactor is used. Injection of steam in this type of systems also serves to reduce the temperature in the reactor due to the limit values. The relationship between mass fraction of solid carbon in the syngas and temperature in partial oxidation reactor as a function of steam to fuel mass ratio for two excess air coefficient are shown in Fig. 2.

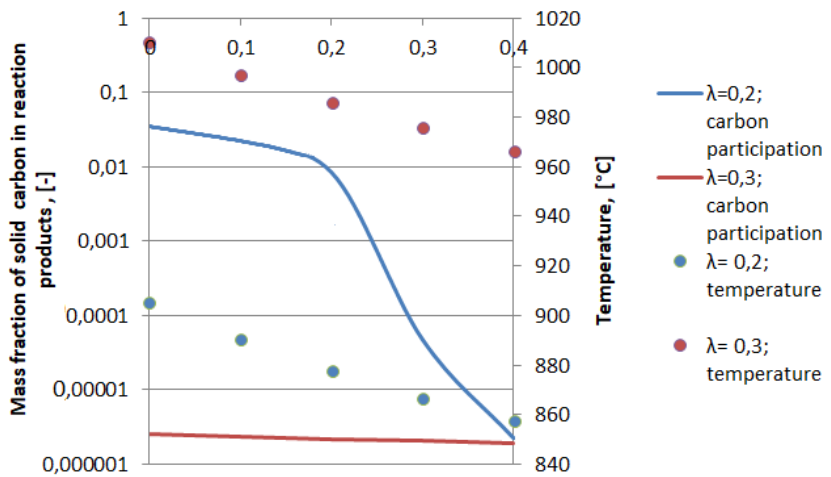

Fig. 2. Graph of mass participation of carbon in syngas and temperature in POR as a functions of steam to fuel mass ratio.

The graph shows that increase of steam - fuel ratio causes a decrease in the share of solid coal fractions in syngas and reduces the temperature in the reactor. It can be observed that for excess air coefficient 0,2 there is a moment of avalanche decrease in the proportion of soot in the gas. In the case of $\lambda=0,3$, the share of the solid carbon fraction is all the case at a low level, even in the absence of water injection (ratio of steam to fuel quantity $=0$ ). This indicates that in the reactor there may be pressure and temperature conditions for which there is no need for steam injection and in the POR large quantities of soot do not occur.

The first optimized parameters were the excess air coefficient $(\lambda)$ in the POR reactor. The case studies calculations included $\lambda$ range from 0,2 to 0,5 . Compressed air flow from caverns, was constant, while the ratio of air fed to POR to the amount of air fed into the syngas combustion chamber was changing. Importantly, it was assumed that the temperature before the expanders cannot exceed $1100^{\circ} \mathrm{C}$, due to the expander's limitations. The temperature limitation in the POR was controlled by the injection steam flow whereas maintaining the permissible temperature in the syngas combustion chamber was controlled by excess air. In addition, it was assumed that the mass participation of soot in the gas can not exceed $1 \cdot 10^{-5}$. To show the graph, the most efficient system configurations that meet all the assumptions and temperature limits were selected with the given excess air coefficient. The relation between the efficiency of the system and excess air coefficient in POR is presented in the Fig. 3.

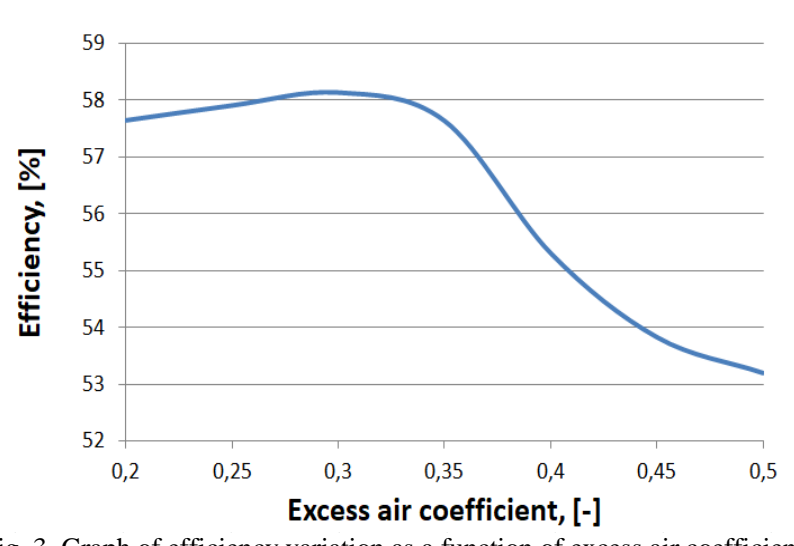

Fig. 3. Graph of efficiency variation as a function of excess air coefficient.

The Fig. 3 shows that the efficiency of the system is the largest in the case of $\lambda$ about 0,3 .

In the next optimization step, for the case of excess air coefficient equal to 0,3 , it was decided to analyze the impact of interstage pressure on the system's efficiency. In addition, possible interstage pressure from 1,4 to $4 \mathrm{MPa}$ was analyzed. The previous assumptions have also been retained. The calculation results are shown in Fig. 4.

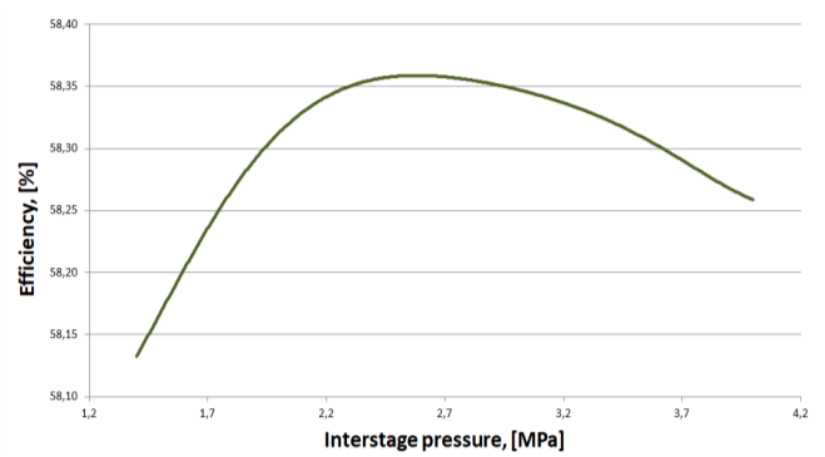

Fig. 4. Graph of efficiency variation as a functions of interstage pressure

TABLE III: ANALYSIS RESULTS

\begin{tabular}{|c|c|c|c|}
\hline \multicolumn{2}{|l|}{ Data } & Value & Unit \\
\hline \multicolumn{2}{|l|}{ Net efficiency } & 58,36 & $\%$ \\
\hline \multicolumn{2}{|l|}{ Fuel stream } & 8,052 & $\mathrm{~kg} / \mathrm{s}$ \\
\hline \multicolumn{2}{|l|}{ Air stream to POR } & 41,559 & $\mathrm{~kg} / \mathrm{s}$ \\
\hline \multicolumn{2}{|l|}{ POR temperature } & 989 & ${ }^{\circ} \mathrm{C}$ \\
\hline \multicolumn{2}{|l|}{ Steam to fuel mass ratio } & 0 & - \\
\hline \multicolumn{2}{|c|}{ Temperature after the combustion chamber } & 1100 & ${ }^{\circ} \mathrm{C}$ \\
\hline \multicolumn{2}{|l|}{ POR excess air coefficient } & 0,3 & - \\
\hline \multicolumn{2}{|c|}{ Combustion chamber excess air coefficient } & 3,86 & - \\
\hline \multicolumn{2}{|c|}{ Air stream } & 417 & $\mathrm{~kg} / \mathrm{s}$ \\
\hline \multicolumn{2}{|l|}{ POR supply pressure } & 4,2 & $\mathrm{MPa}$ \\
\hline \multicolumn{2}{|l|}{ Interstage pressure } & 2,6 & $\mathrm{MPa}$ \\
\hline \multicolumn{2}{|l|}{ Total power } & 368,15 & MW \\
\hline \multicolumn{2}{|l|}{ Net output of electricity } & 5772,47 & GJ \\
\hline \multicolumn{2}{|l|}{ Discharging time } & 4,355 & $\mathrm{~h}$ \\
\hline \multicolumn{2}{|l|}{ Electrical own needs } & 7,3 & MW \\
\hline \multirow{8}{*}{ Syngas mass composition } & $\mathrm{N}_{2}$ & 0,6322 & - \\
\hline & $\mathrm{Ar}$ & 0,0108 & - \\
\hline & $\mathrm{H}_{2} \mathrm{O}$ & 0,0432 & - \\
\hline & $\mathrm{CO}_{2}$ & 0,0344 & - \\
\hline & $\mathrm{CO}$ & 0,2290 & - \\
\hline & $\mathrm{H}_{2}$ & 0,0312 & - \\
\hline & $\mathrm{CH}_{4}$ & 0,0187 & - \\
\hline & $\mathrm{C}$ & $2,56 \cdot 10^{-6}$ & - \\
\hline
\end{tabular}

The graph shows that increasing the pressure rise the 
efficiency of the system, reaching a maximum in 2,6 MPa. Further increase of the interstage pressure brings about a decrease in the efficiency of the system. For optimal value of pressure, system achieves efficiency $58,36 \%$.

Obtained results of most important parameters of the optimal system are presented in Table III.

\section{Comparison of Solutions}

In relation to the reference case a significant efficiency increase was obtained. For comparison, several CAES installations were compared. The set of CAES systems are presented in Table IV.

TABLE IV: COMPARISON OF VARIOUS CAES SYSTEM TECHNOLOGIES [12]

\begin{tabular}{ccccc}
\hline \hline \multirow{2}{*}{ Data } & CAES & CAES & CAES + & \multirow{2}{*}{ Unit } \\
& Huntorf & McIntosh & POGT & \\
\hline GF & 1.56 & 1.17 & 1.09 & $\mathrm{kWh} / \mathrm{kWh}$ \\
$\eta$ & 42 & 54 & 58 & $\%$ \\
\hline \hline
\end{tabular}

GF: gas consumption to energy production factor

The McIntosh CAES power plant differs from the CAES Huntorf case using heat recuperation, where hot exhaust fumes heat the air supplied to the combustion chamber. The comparative table shows that the installation of an energy storage system in compressed air in combination with a partial oxidation gas turbine shows the best efficiency.

\section{CONCLUSION}

For article purposes, thermodynamic analysis of the energy storage system in compressed air with partial oxidation gas turbine was made. During the analysis, the initial optimization of such parameters as: air excess coefficient, steam injection or interstage pressure was performed. The optimization concern to maximize of the energy efficiency of the entire installation. As a result of the optimization, a higher efficiency than the reference system (Huntorf) was obtained, by 16 percentage points. CAES + POGT system was also compared with the CAES system with heat recuperation (McIntosh), where also a higher efficiency value was obtained, by 4 percentage points. The analyzed installation is also characterized by the lowest gas consumption to energy production factor. In addition, the turbine power has been increased from 290 to $368 \mathrm{MW}$, which is a significant change considering that the outgoing air stream remained unchanged. The results of the analysis indicate that the addition of a partial oxidation to the CAES system results in high energy efficiency indicators.

Additionally, the system's efficiency can be increased by utilization the heat produced in the compressor intercoolers. This heat can be used for example, for district heating purposes, creating a cogeneration system.

An additional advantage of the POGT installation is a wide range of possibilities for using synthesis gas, eg in a fuel cell, or for the production of hydrogen [13].

\section{REFERENCES}

[1] O. Palizban and K. Kauhaniemi, "Energy storage systems in modern grids - Matrix of technologies and applications," J. Energy Storage, vol. 6, pp. 248-259, May 2016.

[2] International Electrotechnical Commission, Electrical Energy Storage, Geneva, 2011.

[3] N. Krzysztof, "Magazynowanie, kondycjonowanie i konwersja energii ze źródeł odnawialnych," Wydawnictwo Instytutu Maszyn Przeplywowych PAN, 2014.

[4] H. Lund and G. Salgi, "The role of compressed air energy storage (CAES) in future sustainable energy systems," Energy Convers. Manag., vol. 50, no. 5, pp. 1172-1179, May 2009.

[5] B. Albrecht, "Reactor modeling and process analysis for partial oxidation of natural gas," University of Twente, 2004.

[6] J. Rabovister, J. Pratapas, D. Boulanov, D. Horazak, J. Keiser, and T. Lieuwen, "Partial oxidation gas turbine for power and hydrogen co-production from coal-delived fuel in industrial applications," 2010.

[7] Operating experience with Huntorf air storage gas turbine power station, Brown Boveri. Rev., vol. 73, no. 6, p. 297-305, 1986.

[8] M. Raju and S. K. Khaitan, "Modeling and simulation of compressed air storage in caverns: A case study of the Huntorf plant," Appl. Energy, vol. 89, no. 1, pp. 474-481, 2012.

[9] S. Zhang, J. Chi, and Y. Xiao, "Performance analysis of a partial oxidation steam injected gas turbine cycle," Appl. Therm. Eng., vol. 91, pp. 622-629, Dec. 2015.

[10] S. Briola, P. D. Marco, R. Gabbrielli, and J. Riccardi, "A novel mathematical model for the performance assessment of diabatic compressed air energy storage systems including the turbomachinery characteristic curves," Appl. Energy, vol. 178, pp. 758-772, 2016.

[11] I. H. Bell, J. Wronski, S. Quoilin, and V. Lemort, "Pure and pseudo-pure fluid thermophysical property evaluation and the open-source thermophysical property library coolprop," Ind. Eng. Chem. Res., 2014.

[12] Łukasz Dzierżanowski, "Elektrownie caes," Energia Elektryczna, vol. 2-3, 2011.

[13] J. K. Rabovitser, N. Serguei, and D. J. White, "Partial oxidation gas turbine (POGT) cycles," The Gas Turbine Handbook, U.S. Department of Energy Office of Fossil Energy National Energy Technology Laboratory, 2006, pp. 121-125.

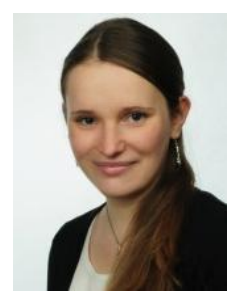

projects.
Marlena Wróbel has graduated from Silesian University of Technology in 2016 obtaining witch distinction master of science degree in power engineering. Her specific field of interest is energy accumulation and energy management. Currently she is a PhD student in Institute of Thermal Technology where she is analyzing compressed air energy storage technologies and energy storage hybrid systems. Apart of academic activities she is also involved in industrial

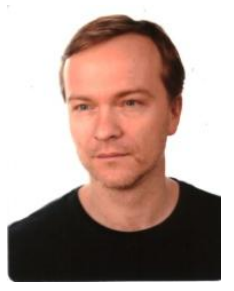

Jacek Kalina has been working in the field of energy systems engineering for more than twenty years. He graduated in 1997 from Silesian University of Technology, Poland, where he also obtained Ph.D. and D.Sc. degrees. The specific fields of his interests are power and cogeneration plants, small-scale cogeneration and tri-generation, modelling of industrial thermal and flow processes, utilisation of waste energy in industry, economic problems of construction and exploitation of energy conversion plants, technical-economic optimisation of thermal energy systems, energy management, policy and market studies. He gained international scientific experience during long term stays at University of Ulster, Northern Ireland, Universite Catholique de Louvain in Louvain-la-Neuve, Belgium and University of Florence, Italy. She also took industrial training at GE Jenbacher AG, Austria. Apart of the academic activity he was also strongly involved in many industrial projects. 